Hoffmann, E. - A Desconstructionist Reading

\title{
"Brücke dreht sich um!". A Deconstructionist Reading of Kafka's "Die Brücke"
}

http://dx.doi.org/10.1590/1982-88372036

Eva Hoffmann ${ }^{1}$

\begin{abstract}
Franz Kafka's (1883-1924) "Die Brücke" is one of the less well-known texts by one of the most prolific authors of literary modernity. However, this short prose text embodies prevalent questions of literary modernity and philosophy as it reflects the crisis of language in regard of identity, communication, and literary production. Placed in the context of fin-de-siècle's discourse of language crisis, this article provides a dialogue between Kafka's "Die Brücke" and Hannah Arendt's (1906-1975) philosophy of thinking and speaking in The Life of the Mind. Contrary to Arendt's understanding of the metaphor as "a carrying over" between the mental activities of the solitude thinker and a reconciliation with the pluralistic world shared with others, this article argues for a deconstructionist reading of "Die Brücke" as a tool to reevaluate Arendt's notion of a shared human experience ensured through language and illustrates the advantages of poetic texts within philosophical discourses.
\end{abstract}

Key-words: Kafka, Hanna Arendt; Derrida; language; metaphor

Zusammenfassung: "Die Brücke" von Franz Kafka (1883-1934) ist einer der weniger beachteten poetischen Texte des Autors. Dieser Artikel argumentiert für die Relevanz dieses Prosastückes innerhalb des Diskurses der literarischen Moderne und der Philosophie hinsichtlich von Fragen nach Identitäts- und Sprachkrise und der Möglichkeit von literarischer Produktion. Indem ein Dialog zwischen Kafkas poetischem Text und Hannah Arendts (1906-1975) Philosophie des Denkens und des Sprechens in The Life of the Mind hergestellt wird, zeigt dieser Artikel wie Kafkas "Brücke" Arendts Verständnis einer Verbindung zwischen der geistigen Welt und der Welt als pluralistischen Ort, den wir mit anderen Menschen teilen, dekonstuiert und folglich auch die Annahme menschlicher Grunderfahrungen und ihrer Mitteilbarkeit in Frage stellt. Damit thematisiert dieser Artikel auch die Vorteile poetischer Texte innerhalb des philosophischen Diskurses.

Stichwörter: Kafka, Hannah Arendt; Derrida; Sprache; Metapher

\footnotetext{
${ }^{1}$ University of Oregon, Department of German and Scandinavian. Email: evah@uoregon.edu

Pandaemonium, São Paulo, v. 17, n. 24, Dez. /2014, p. 20-36
} 
Hoffmann, E. - A Desconstructionist Reading

\section{Introduction}

Hannah Arendt's philosophy on language and thinking is in stark contrast with Franz Kafka's fictional prose text "Die Brücke" (1916/1917), which concerns itself with the same subject matter of bridging an abyss. In The Life of the Mind, Arendt depicts how thinking manifests itself through speech. The urge to speak, Arendt explains, is a sign for the quest of meaning; a process during which the thinking ego seeks to attest his or her mental activities both to the world of appearances and to him- or herself. While we withdraw from the world of appearances into the realm of concepts and abstractions during the act of thinking, our common sense and our belonging to the sensory world requires examples to illustrate abstract concepts. "At this point," ARENDT (1971: 103) continues, "metaphor comes in. The metaphor achieves the 'carrying over' [...] the transition from one existential state, that of thinking, to another, that of being an appearance among appearances, and this can only be done by analogies."

Kafka's "Brücke," however, presents the reader with traffic between the sensory and the non-sensory world that is marked with failure and ultimately leads to violence and destruction. Kafka's bridge, which is also the narrator of the story, collapses in the very moment a wanderer approaches it for the first time - a moment for which the bridge desperately has been waiting. Despite the bridge's best intention to hold up the traveler entrusted to it ("halte den dir Anvertrauten"), it is terrified by an abrupt and forceful leap the wanderer undertakes on its back (1969: 327). Struck by the sudden pain the bridge has not anticipated, it turns around to see who inflicted such pain on it and despite the realization of its mistake — "Brücke dreht sich um!" — falls into the abyss and is pierced by the once peacefully stones "die mich immer so friedlich aus dem rasenden Wasser angestarrt hatten” (1969: 327).

Contrary to ARENDT's (1971: 105) elated account, in which the metaphor is "bridging the abyss between inward and invisible mental activities and the world of appearances," and thus can be seen as "the greatest gift language could bestow on thinking”, Kafka's text paints a bleaker picture. For ARENDT (1971: 110), metaphorical 


\section{Hoffmann, E. - A Desconstructionist Readins}

language — itself metaphorically illustrated as a bridge — not only makes the transcendence between the sensory world and the non-sensory world possible, but also abolishes this difference altogether: "There are no two worlds because metaphor unites them.". Opposed to this logic, Kafka's "Brücke" creates an image of writing as alienation and embodies the experience of "what it means to be outside of everything, even outside of oneself" (MILLER 1991: 19).

This article provides a deconstructionist reading of Kafka's text. Referring to deconstructionist criticism and its representatives like Jacques Derrida, Paul de Man, and J. Hillis Miller, it illustrates how the story deconstructs its own writing process in its impossibility to transcend the abyss between the world of appearances and the metaphysical realm, the signified and the signifier, origin and presence, and subject and object. Kafka's text is then placed within the context of the language skepticism of finde-siècle's modernity to reevaluate Arendt's notion of language - and specifically the metaphor - as a reconciliation between the thinking ego and the world. Exploring the paradoxical structure of Kafka's text, the article illustrates finally how the paradoxes and aporias of a poetic text can lend themselves to a philosophical inquiry beyond the formulation of a preconceived and universal truth.

\section{Longing for presence: language and the metaphysical tradition of western thought}

According to Jacques Derrida, any deconstructionist reading of a text must begin by identifying "the fundamental conceptual oppositions they rely on: speech-writing, soulbody, intelligible-sensible, literal-metaphorical, natural-cultural, masculinefeminine...[his goal is to] subject these oppositions to an internal critique that destabilizes them" (HONDERICH 1995: 180). The binary opposition (Derrida refers to this

idea as logocentrism) shows "the conceptual movement of thought which calms movement in favor of locating centers, origins, essences" (DERRIDA 1974: 274). It thus 
Hoffmann, E. - A Desconstructionist Reading

refers to the idea of presence and works to the favor of the Western metaphysical tradition that privileges one side of the term over the other.

In the chapter Linguistics and Grammatolgy in Of Grammatology, Derrida criticizes Ferdinand de Saussure's system of linguistics for having launched the binary sign without proceeding to erase it (DERRIDA 1974: 63). Derrida's grammatology diagnoses in the oppositional structure of the sign a longing for presence that runs through the tradition of Western thought. In order to open up the reliability of language to rhetorical questioning, deconstruction acts as a "constant reminder of the ways in which language deflects or complicates the philosopher's project" (Norris 1982: 19). Norris (1982: 19) writes:

Above all, deconstruction works to undo the idea - according to Derrida, the ruling illusion of Western metaphysics - that reason can somehow dispense with language and arrive at a pure, self-authenticating truth or method.

\section{3 "Under erasure:" metaphor and the suspension of meaning}

Rather than a correspondence between thought and word, the collapse of the bridge in Kafka's story illustrates how language is both inevitable and unreliable. Language is a differential network of meaning, which refuses the determination of a one-to-one link between signifier and signified (NORRIS 1982: 24). Influenced by Friedrich Nietzsche's "continuous sign-chains," without origin and end in "truth," Derrida reads the entire notion of semiosis as a suspension of meaning, which constantly escapes the structure of presence (SPIVAK 1974: xliii). "The sign cannot be taken as a homogenous unit bridging an origin (referent) and an end (meaning), as 'semiology,' as the study of signs, would have it," Spivak writes in regard to Derrida (SPIVAK 1974: xxxix).

The metaphor is the structure, in which presence is always marked through absence and the gesture represents the very thing it keeps absent. In this paradoxical double bind of presence and absence, the sign is always inhabited by another sign and must thus be read "under erasure" (DERRIDA 1974: 72). Instead of meaning, the reader is confronted with the indefinable deferring of meaning, which is only partly 


\section{Hoffmann, E. - A Desconstructionist Readins}

comprehensible through its negativity, its absence, and the difference to what-it-is-not. In this way, Derrida introduces the term différance as the "structure that deconstructs structuralism” (SPIVAK 1974: 1xi).

Kafka's "Brücke" and the violent and graphic death of its protagonist inscribe "writing under erasure" into the configurations of the text. Kafka's bridge is the crossed out sign, which collapses the very moment it comes into use. The text dismantles any structure of binary oppositions as a mere comforting illusion of presence as it is conserved in the Saussurian sign (SPIVAK 1974: xl). Derrida's grammatology shows no nostalgia for the lost presence that encapsulates the unity of word and thing and hence the loss of origin and end. In fact, he determines metaphor as the sign by "the trace or track of that other that is forever absent" (SPIVAK 1974: xviii). The trace is thus the mark of the absence of a presence, an always already absent presence. Derrida uses terms like différance and trace as "non-synonymous substitutions," which operate in "a similar dislocating fashion to describe the unfolding of the functioning structure of a concept" (HONDERICH 1995: 268). In Writing and Difference, DERRIDA (1974: 403) clarifies the nature of the trace:

The trace is not a presence but is rather the simulacrum of a presence that dislocates, displaces, and refers beyond itself. The trace has, properly speaking, no place, for effacement belongs to the very structure of the trace. . . . In this way the metaphysical text is understood; it is still readable, and remains read.

Kafka's "Brücke" can thus be read as the metaphoric crossing out of the sign, leaving nothing but the traces of the torn bridge at the bottom of the abyss, replacing the Saussurian sign with the fragmented trace.

\section{A bridge to the world of appearances: Arendt's thinking ego and the metaphor}

In a similar vain, the 'life of the mind' seems to occupy a dislocated, non-existing space in Arendt's philosophy. Arendt argues that thinking always requires the withdrawal of the 
Hoffmann, E. - A Desconstructionist Reading

thinking ego from the world of appearances. It is an invisible activity separated from all things. It takes place in solitude when the mind is secluded from the world around it. Through representing sensory objects and non-sensory matters, the mind transcends time and space, "To put it quite simply, in the proverbial absent-mindedness of the philosopher, everything present is absent because something actually absent is present to his mind..."(ARENDT 1971: 84).

Thinking it thus "always out of order, interrupts all ordinary activities and is interrupted by them" (ARENDT 1971: 197). However, the activity of thinking for Arendt never loses its connection with practice and the reality of the world we live in. Although all human beings are thinking beings, we are also grounded in the world of appearances. Taking up Plato's story in the Theaetetus about the philosopher Thales who fell into a well while looking at the stars, provoking the laughter of a peasant girl from Thrace, Arendt believes that the philosopher's own common sense must be alert enough to anticipate this laughter (ARENDT 1971: 83).

Thinking is only one of the many human faculties, and the "philosopher's own common sense makes him aware of being 'out of order' while engaged in thinking" (ARENDT 1971: 80). In what ARENDT (1971: 83) describes as the "intramural warfare" between common-sense reasoning and speculative thinking, the thinking ego possesses both common sense reasoning and the faculty of thinking. ARENDT (1971: 81) points out that "all the metaphysical questions that philosophy took as its special topics arise out of the ordinary common-sense experiences."

Arendt thus argues for the primacy of the world of appearances. While he or she abstracts and represents objects from the world of appearances through the faculty of imagination, the thinker withdraws from reality only to be called "back into the world of appearances" (ARENDT 1971: 185). Thinking and living accompany each other and the mind turns continuously towards life in its quest to understand its meaning. Thus, instead of dividing the world of appearances from the realm of thinking, Arendt links them together. As human beings, we have the urge not only to think and therefore withdraw from the world of appearances occasionally, but also to reconcile our thinking with reality through common sense. Eventually the thinking ego experiences the "urge to 
Hoffmann, E. - A Desconstructionist Reading

speak and thus make manifest what otherwise would not be part of the appearing world at all” (ARENDT 1971: 98).

Since thinking deals with invisibles, we need metaphorical language as a tool to express our thoughts. However, language, by lending itself to metaphorical usage, enables us also to think, that is, to have traffic with non-sensory matters, because it permits a carrying-over of sense experiences (ARENDT 1971: 103). Thus, metaphorical language can be seen as the bridge that holds the two worlds together and closely binds the thinking ego to the world of appearances, "Analogies, metaphors, and emblems are the threads by which the mind holds on to the world even when, absentmindedly, it has lost direct contact with it, and they guarantee the unity of human experience" (Arendt 1971: 109).

\section{The unity of human experience? - Kafka and the crisis of language}

It is precisely the alleged "unity of human experience" and its communicability that enables both thinking and speaking, that Kafka's texts put into question. In the tradition of the language crisis, which "found such abundant expression in the $20^{\text {th }}$ century" (Kovach 2002: 85), "Die Brücke" depicts a world, in which expression of thought into words and the transference of the life of the mind into the world of appearances through language becomes questionable. The text hence reflects the limits of language as a tool to express reality, and testifies in the tradition of writers such as Hugo von Hofmannsthal (1874-1929) "to the problematic nature of the external world and the self" (KovACH 2002: 4).

For ARENDT (1989: 40), thinking gets bestowed with meaning and truth in the pluralistic act of judging:

Also, it is of course by no means true that you need or can even bear the company of others when you happen to be busy thinking; yet, unless you can somehow communicate and expose to the test of others, either orally or in writing, whatever you may have found out when you were alone, this faculty exerted in solitude will disappear. In the words of Jaspers, truth is what I can communicate.

Pandaemonium, São Paulo, v. 17, n. 24, Dez. /2014, p. 20-36 
Hoffmann, E. - A Desconstructionist Reading

Through communicating and thus testing my thoughts against the opinions of others, thinking attains a form of truth that it can never obtain in the solitary act of thinking itself. Just as our sense of reality and worldliness depends on the communicability of our thoughts, we can lose our faculty of thinking without communication and interaction with one another.

For Kafka and other thinkers and writers in the tradition of fin-de-siècle's crisis of language, inner experiences cannot claim any value of 'truth,' not even for the individual. Influenced by Ernst Mach's dictum (1838-1916) — "Das Ich ist unrettbar" — identity is understood only in the modus of irretrievable loss. The modern self is in crisis and with it its cognitive capabilities and possibilities to communicate with others. It is under these premises, as Ellen RITTER (2002: 77) writes, that "a distanced mode of expression arises," "a language of mediacy."

Hugo von Hofmannsthal's famous expression of the crisis in language in literary modernity, which he expresses quite articulately in Ein Brief, proves to be a prevalent question for writes and thinkers of the twentieth century and beyond. Thomas Kovach (2002: 94) writes:

And finally, Chando's crisis points to what was become a central preoccupation of the $20^{\text {th }}$ century, reflected in the philosophy of Wittgenstein, as well as in the more recent developments such as Jacques Derrida's deconstruction: namely the demonstration that language can no longer be relied on as a valid signifier of a reality which exists outside itself, and in fact that we cannot ever experience a "reality" which is not already mediated by our language.

While Arendt tries to rescue both the cognition of the individual and the common sense reality of a shared world through (metaphoric) language, Kafka's text testifies to "the dilemma of a language that has lost its connection with reality" (KovACH 2002: 91). Instead of presenting metaphor as "the greatest gift language could bestow on thinking" (ARENDT 1971: 105), Kafka's text displays a radical openness in the image of the torn bridge at the end of the text. As Kafka writes in his diary (1948: 121): "Nur so kann geschrieben warden ... mit solcher vollständigen Öffnung des Leibes und der Seele.” The 
Hoffmann, E. - A Desconstructionist Reading

text thus embodies into its configurations the quest for meaning in the light of the self and its language, which is no longer reliable. RITTER (2002: 74) writes:

What constitutes the importance of the work in literary history, though, isthe manner, in which the form is fully congruent with the content, indeed that the content is portrayed equally through the form of the narrative as through the action itself $[\ldots]$.

\section{Sliding paradoxes and the poetics of truth}

The collapse of the bridge that causes its violent death ("zerrissen und aufgespiesst") bears despite of its brutality a certain wit due to the paradoxical tension of its long anticipation of the wanderer and its failure upon his arrival. However, as WEITZMANN (2011: 592) points out, Kafka's "paradox-mechanisms of wit" are fundamentally different from Kant's, where these moments still act as a "Vehikel oder Hülle für die Vernunft und deren Handhabung für ihre moralisch-praktischen Ideen” (KANT 2002: 131).

Far from containing a morality or aiming at the reader's mere amusement, Kafka's text calls into question the metaphysical assumptions of Western thought as the correspondence of mind and appearance as well as the transcending role language can play in it. WEITZMANN (2011: 594) concludes: "Kafka's play with the play of paradox ... will also be a means by which to reexamine of some of the most basic questions of philosophical inquiry." Thus, the playfully aesthetic paradox discloses the rhetorical nature of philosophic arguments, which turns literature and with it the critic in a strong position to counter philosophy's long held prejudices against poetic texts (NORRIS 1982: 21).

It is precisely because of the acknowledgment and exploitation of the own rhetorical status that puts literature and literary theory in a privileged position over philosophical discourses. De MAN (1986: 13) writes: "Literature turns out to be the main topic of philosophy and the model of the kind of truth to which it aspires." 


\section{Hoffmann, E. - A Desconstructionist Readins}

Deconstruction as a critical theory questions the tradition of Western thought and "refuses to grant philosophy the kind of privileged status it has always claimed as the sovereign dispenser of reason" (NORRIS 1982: 18). Thus, a deconstructionist reading of Kafka's text challenges Western philosophy's belief in language as the binding element between thought and sensual experience.

The bridge's anticipation of its own death at the beginning of the story — "So lag ich und wartete; ich musste warten. Ohne einzustürzen kann keine einmal errichtete Brücke aufhören, Brücke zu sein" — must be read as an acknowledgement of the impossibility of self-presence and origin. DERRIDA (1974: 61) writes:

The value of the transcendental arche [origin] must make its necessity felt before letting itself be erased. The concept of the arche-trace must comply with that necessity and that erasure. It is in fact contradictory and not acceptable within the logic of identity.

Kafka playfully alludes to this necessity by varying its structure to the "almost necessity." As WEITZMANN (2011: 592) points out, the "almost necessary" occurs frequently in Kafka's work and "constantly provides the criteria for situations and actions that are just as lamentable as they are amusing and as amusing as they are lamentable." She continues (2011: 592): "Seeming inevitability and logical circularity not only provides a certain comic tension, but furnishes the whole inner impetus and mechanism of the plot at large." The "almost necessary" structure is settled between the superfluous and the necessary, and is thus more than the paradoxical reversal of expected logic. It cannot be "rereversed" into its "original truth" and remains a "permanent paradox" that cannot be dissolved (WEITZMANN 2011: 594). Kafka's text hence testifies to the aporetic structure of reason itself, while at the same time resurrects 'truth' by locating the collapse of the bridge within the realm of the 'almost necessary.' The fact that the bridge becomes a bridge only through and by collapsing — "Ohne einzustürzen kann keine einmal errichtete Brücke aufhören, Brücke zu sein" — which at the same time determines the end of its life and functionality, is indeed a brilliant display of Kafka's mechanisms of paradoxical wit. 
Hoffmann, E. - A Desconstructionist Reading

Kafka's sliding paradoxes, NEUMANN (1968: 706) writes, "lenken nicht auf eine Synthese des Widersprüchlichen hin, wie das traditionelle Paradox, sondern von jeder erwarteten Stimmigkeit ab; jede Auflösung ist bloß eine Reduktion auf neuerlich und viel ursprünglich Unbegreifliches." "Die Brücke" therefore embodies an aporia that constantly escapes its determination to an unequivocal meaning. Aporia, Terry EAGLETON (2003: 275) points out, "is the impass of meaning, where texts get into trouble, come unstuck, offer to contradict themselves."

\section{Kafka's bridge - a hybrid dislocated in the alienation of modernity}

The controversial and thus aporetic structure is already embodied in the ambivalent characteristics of Kafka's bridge and its narrative style. As the narrating I, the bridge also refers to itself in the third person, questioning the boundaries of subject and object. At the same time, the bridge inhabits human traits - its anthropomorphic embodiment includes hands, feet, and hair - and was yet erected to fulfill the mere role of transporting the traveler from one side of the abyss to the other. The hybrid nature of the bridge inaugurates the paradoxical disposition of the text into its very own structure. The bridge is a thinking entity that is fully endowed with the capacities of thought and the faculty to feel pain. In a gesture that appears to be fully human, it aspires to fulfill its entrusted role as a tool of transportation. KAFKA (1969: 327) writes:

Strecke dich, Brücke, setze dich in Stand, geländerloser Balken, halte den dir Anvertrauten. Die Unsicherheit seines Schrittes gleiche unmerklich aus, schwankt er aber, dann gib dich zu erkennen und wie ein Berggott schleudere ihn ans Land.

The paradoxical nature of the bridge combines human traits and even traces of megalomania, and its confinement to the mere status as an object of traffic, creates a comical relief to the inherent violence of the plot. However, the moment the bridge turns around to look at his tormentor, the story shifts into the fatedness of tragedy. Thus, Kafka's bridge finds itself falling into the depth of the abyss while desperately crying out, 
Hoffmann, E. - A Desconstructionist Reading

"Brücke dreht sich um" (1969: 327). Kafka's bridge struggles with a quest for meaning that eludes the grasp of a self-present awareness. Identity is marked through selfdifferentiation and self-postponement, which dismantles subjectivity as a transcendental term. Kafka's "Brücke" thus deconstructs language in terms of a trace-structure, effacing it even as it presents its legibility (SPIVAK 1974: xviii).

Contrary to Arendt's idealistic view on language as a bridge that unifies the world of appearances and the world of thought, and enables one to feel at home in both, Kafka's "Brücke" experiences the dislocation and estrangement of modernity. "The crucial importance of Kafka for twentieth-century thought," Miller (1991: 23) writes, "lies not only in his extreme experience of the loss of self-hood, but also in his deep exploration of the tangled relationships of writing and salvation." Kafka's diaries are full of descriptions of his inner emptiness resulting from the disastrous withdrawal into one's own center. Our time is marked by a broken link between a subject and his or her object, be it the self, God, or the fellow human being. The fact that the other can only be experienced through his or her absence can be seen in the revealed identity of the wanderer of Kafka's "Brücke:" "Wer war es? Ein Kind? Ein Traum? Ein Wegelagerer? Ein Selbstmörder? Ein Versucher? Ein Vernichter?” (KAFKA 1969: 327).

Thus, the collapse of the bridge and its struggle to hold on to both sides of the abyss reflects the experience of the self in modernity, which denies a meaningful existence within the community of other people. This isolation of the individual can be seen in Kafka's text through the fact that the bridge is situated in an impassable height that no one has ever strayed to and that is not traced on any map: "Kein Tourist verirrte sich zu dieser unwegsamen Höhe, die Brücke war in den Karten noch nicht eingezeichnet" (KAFKA 1969: 327). A crumbling and dissolving ground, onto which the bridge firmly holds, marks both sides of the abyss. KAFKA (1969: 327) writes:

Diesseits waren die Fußspitzen, jenseits die Hände eingebohrt, in bröckelnden Lehm habe ich mich festgebissen. Die Schöße meines Rockes wehten zu meinen Seiten. In der Tiefe lärmte der eisige Forellenbach. ... 
Hoffmann, E. - A Desconstructionist Reading

In their mysterious images, descriptions, and actions, Kafka's poetic texts are figural embodiments of his inner life and his situation in the world as a state of alienation. They reflect what it means to be "outside of everything, even outside of oneself" (MILLER 19). "It is as if I were made of stone," KAFKA (1948: 27) writes in his diary, "I have become cold again, and insensible." This experience is reflected in the bridge's self-description; "Ich war steif und kalt, ich war eine Brücke, über einen Abgrund lag ich" (KAFKA 1969: 327). Once the metaphysical link between the thinking ego and the outside world is broken, the individual is lost in the eternal circularity of its own thoughts: "Einmal gegen Abend war es - der erste, war es der tausendste, ich weiss es nicht, - meine Gedanken gingen immer in einem Wirrwarr und immer in der Runde” (KAFKA 1969: 327).

\section{Writing: "outside the self — in itself"}

Writing, it may seem, is the one action which, depending on nothing outside the self, and deriving from a voluntary and autonomous exercise of the power to transform things into words, can stop the fall into the abyss (MILLER 1991: 23). Striving for a comfort in writing, KAFKA (1948: 212) arrogates to himself the almost divine powers of someone who obtains a "higher type of observation." This is reflected in the bridge's emphatic attitude with which it will carry out the transport of the traveler "wie ein Berggott" (KAFKA 1969: 327).

However, Kafka's relation to writing remains within the aporetic structure of a yearning for connection with the world and its fellow men. MiLleR (1991: 24) writes: "Far from being able to escape out of his own inner emptiness into the solidity and coherence of a story, Kafka is repulsed by the broken fragments of incomplete ones, and kept outside of the void, hanging on, as it were, with both hands. Kafka finally recognizes that the attempt to reach out and connect through literature is impossible, because "the space of literature is, par excellence, the place of separation" (MILLER 1991: 27).

In his diary, KAFKA (1948: 77) writes:

What will be my fate as a writer is very simple. ... I waver, continually fly to the summit of the mountain, but then fall back in a moment. Others waver too, but in lower regions, 


\section{Hoffmann, E. - A Desconstructionist Readins}

with greater strength; if they are in the danger of falling, they are caught up by the kinsman who walks beside them for that very purpose. But I waver on the heights; it is not death, alas, but the eternal torments of dying.

In this context, Kafka's text deconstructs itself by pointing towards its own aporia that renders writing futile. However, it is precisely in the absence of specifications, as Miller (1991: 295) points out, "multiplies the poems' powers over the reader to a hundredfold." Through the "significance of the missing names" — which appears in Kafka's text as a performative aspect, leaving the answers concerning the identity of the traveler unanswered - that creates the power of the poetic text to "haunt their readers, to stick in the mind and lodge there permanently, as an ache or throb the reader can never outgrow..." (MILLER 1991: 295).

Deconstruction contrasts the nostalgia for the lost presence with the Nietzsche's affirmative joy, which is reflected in the paradoxical wit of Kafka's poetic texts. In this respect, Nietzsche appears as a forerunner of Derrida and de Man who insist on the ambivalent and aporetic character of philosophical, linguistic, and literary problems (Zima 1999: 150). Derrida (1974: 272) interprets the metaphor as an "outside the self in itself." It thus bears the possibility to restore meaning to a text stripped off of its metaphysical reading. On the ambivalent structure of origin and trace, DERRIDA (1974: 161) writes:

The trace is not only the disappearance of origin, ... it means that the origin did not even disappear, that is never constituted except reciprocally by a non-origin, the trace, which thus becomes the origin of the origin.

In the image of the scattered bridge at the end of the story, the text points toward its own openness and encapsulates a performative aspect. It calls out for the reader to collect the broken pieces and transform them into meaning. It this way, the traces of the bridge bear within themselves the presence and the loss of an origin that can be put together reciprocally and becomes the origin of the origin as the bridge reappears in its own title of “Die Brücke.” DERRIDA (1987: 427) writes:

Turned towards the presence, lost or impossible, of the absent origin, the structuralist thematic of broken immediateness is thus the sad, negative, nostalgic, guilty, Rousseauist 
Hoffmann, E. - A Desconstructionist Reading

aspect of the thought of play which the Nietzschean affirmation - the joyous affirmation of the play of the world and of the innocence of becoming, the affirmation of a world of signs without fault, without truth, without origin, offered to an active interpretation would be the other side.

Kafka's "Brücke" presents us with both - the nostalgia for a lost presence captured in the bridge, who is desperately holding on to both sides of the abyss, and the joyous affirmation of a world stripped of its apodeictic meaning represented in the wanderer and its playful will to destruct the bridge. Through its aporetic structure, evoked through the metaphorical imagery of the bridge and its remaining traces, "Die Brücke" evokes a performative power that creates its recipient in the act of writing. "Writing is a dislocation in the sense that it moves the soul itself of the writer, as well as of the recipient, beyond or outside of itself, over there, somewhere else" (MILLER 1991: 289).

It is in this context that we can and must reconsider the question of literature and philosophy and their relationship to each other. As Derrida (1987: 147) in his reading on Kafka's story "Vor dem Gesetz" points out, there is a place "for all literature to exceed literature." In fact, it is the very nature of literature to go over and beyond itself, to the point where literature would no longer be literature if it were 'only' literature. Just as Kafka's bridge would stop being a bridge if it were not for its ultimate collapse, the text belongs to and is 'literature' as it shows the very breakdown of a logocentric discourse and its underlying binary structures, as well as the role of literature within its deconstruction, which no longer authorizes us to make such a judgment.

\section{Conclusion}

Kafka's "Brücke" deconstructs the idea of an alleged rescue that links the metaphysical realm with the world of experiences. The text refuses to provide a transfer for the thinking ego, and violently crosses out the possibility of "carrying over" and thus connecting with our fellow men. John CAPUTO (1997: 271) writes:

The very meaning and mission of deconstruction is to show that things - texts, institutions, traditions, [etc.] ... - do not have definable meanings and determinable missions, that they are always more than any mission would impose, that they exceed the

Pandaemonium, São Paulo, v. 17, n. 24, Dez./2014, p. 20-36 
Hoffmann, E. - A Desconstructionist Reading

boundaries they currently occupy ... A 'meaning' or a 'mission' is a way to contain and compact things, like a nutshell...the very idea is to crack it open and disturb its tranquility ... cracking nutshells is what deconstruction is.

The power of Kafka's texts lies in their figurative language through which they remain open for the quest of meaning. The openness of what Derrida calls 'the trace' cannot be represented by a theoretical text, but needs to be embodied into the configurations of a poetic text. The isolation of alienation and the crisis of language the modern self experiences is encapsulated in Kafka's "Brücke," which testifies to the only way writing becomes possible. For the Kafkan protagonist, dislocated from his or her origin and faced with the threat of meaninglessness in a world that has lost its metaphysical belief, this openness can only be a painful experience, marked by the violence of the "cracking open." Rather than ARENDT's (1989: 40) belief in truth as something "I can communicate," Kafka shares his fate with the protagonists in his stories. He remains true to the endless wavering, until - paradoxically, as MILLER (1991: 30) points out — "his work became the falsehood which testifies to the truth, the wavering which reveals the goal even though the goal is never reached."

The question as to whether or not 'the goal is reached' in Kafka's "Brücke" remains to be determined by the reader and his or her imagination. After all, we do only know the tragic fate of the bridge - fulfilling its destiny by devastatingly failing it — but we will never know whether or not the wanderer will make it to the other side of the abyss. Arendt's observation - we do not know where the thinker goes when engaged in the absent-minded act of thinking - is perhaps even more accurate for the reader. But Kafka's text certainly calls us back into the world of appearances - a world we ultimately share and all can relate to in its paradoxical loss of meaning.

\section{Bibliographic references}

ARENDT, Hannah. The Life of the Mind. New York and London, Harcourt Brace Jovanovich, 1971. . Lectures on Kant's Political Philosophy. Chicago, University Press, 1989. 
Hoffmann, E. - A Desconstructionist Reading

CAPUTO, John D. Deconstruction in a Nutshell: A Conversation with Jacques Derrida. New York, Fordham University Press, 1997.

DE MAN, Paul. Resistance to Theory. Minnesota, University Press, 1986.

derrida, Jacques. “Avant la Loi”. Trans. Avital Ronell. In: Udoff, Alan (ed.). Kafka and the Contemporary Critical Performance. Bloomington, Indiana University Press, 1987, 128127.

Of Grammatology. Trans. Gayatri Chakravorty Spivak. Baltimore, John Hopkins University Press, 1974.

Writing and Difference. Trans. Alan Bass. Chicago, University Press, 1978.

EAgLETon, Terry. After Theory. New York, Basic Books, 2003.

Honderich, Tod. The Oxford Companion to Philosophy. Oxford, University Press, 1995.

KAFKA, Franz. Die Brücke. In: Raabe, Paul (ed.). Sämtliche Erzählungen. Frankfurt am Main, S. Fischer, 1969. 327.

Diaries: 1910-1913. Ed. Max Brod. Trans. Joseph Kresh. New York, Schocken, 1948.

KANT, Immanuel. Anthroplogie in pragmatischer Hinsicht. Ed. Reinhard Brandt. Hamburg, Meiner, 2000.

Kovach, Thomas A. Hofmannsthal's "Ein Brief:" Chandos And His Crisis. In: Kovach, Thomas A. (ed.). A Companion to the Works of Hugo von Hofmannsthal. Rochester, Camden House, 2002. 85-96.

"Hugo von Hofmannsthal Today." In: Kovach, Thomas A. (ed.). A Companion to the Works of Hugo von Hofmannsthal. Rochester, Camden House, 2002. 1-7.

NeumanN, Gerhard. „Umkehrung und die Ablenkung: Franz Kafkas 'Gleitendes Paradox.'“ In: Deutsche Vierteljahrsschrift für Literaturwissenschaft und Geistesgeschichte. 42, 1968, 702-44.

MiLler, J. Hillis. "Franz Kafka and the Metaphysics of Alienation.” In: Miller, J. Hillis (ed.). Tropes, Parables, Performatives. Duke, University Press, 1991, 15-32.

NORRIS, Cristopher. Deconstruction: Theory and Practice. London and New York, Methuen, 1982.

RITTER, Ellen. "Hofmannsthal's Narrative Prose". In: Kovach, Thomas A. (ed.). A Companion to the Works of Hugo von Hofmannsthal. Rochester, Camden House, 2002. 65-84.

SPIVAK, Gayarti Chakravorty. Foreword. In: Derrida, Jacques. Of Grammatology. Baltimore, John Hopkins University Press, 1974, Ix-xc.

WeitzmanN, Erica. Almost Necessary: Kafka's Kantian Situation Comedy. MLN 126, 2011, 591-613.

ZIMA, Peter. "The Nietzschean Aesthetics of Deconstruction." In: Zima, Peter (ed.). The Philosophy of Modern Literary Theory. University Press, 1999, 141-173.

Recebido em 10/08/2014

Aceito em 29/09/2014

Pandaemonium, São Paulo, v. 17, n. 24, Dez. /2014, p. 20-36 